\title{
Peregrine Falcon Surveys and Monitoring in the Northeast Boreal Region of Alberta, 2001
}

\section{Fish \& Whidife Division}

WILUIFE CONSERMIION AWD BlODIVERSII SECHION

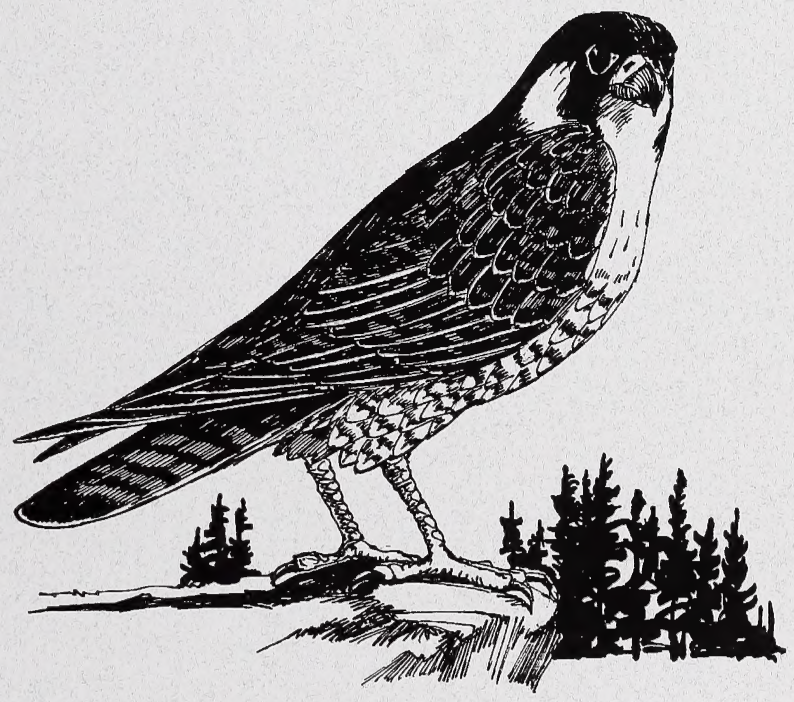

Alberta Species at Risk Report No. 57 



\title{
Peregrine Falcon Surveys and Monitoring in the Northeast Boreal Region of Alberta, 2001
}

\author{
Rob Corrigan
}

Alberta Species at Risk Report No. 57

April 2002

Project Partners:

Sustainable Resource DEVELOPMENT

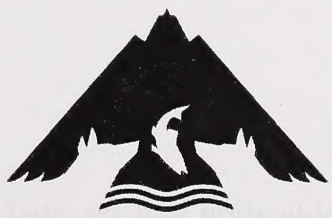

Alberta Conservation Association 
Publication No.: I/083

ISBN: 0-7785-2315-2 (Printed Edition)

ISBN: 0-7785-2316-0 (On-line Edition)

ISSN: 1496-7219 (Printed Edition)

ISSN: 1496-7146 (On-line Edition)

Illustration: Brian Huffman

For copies of this report, contact:

Information Centre - Publications

Alberta Environment / Alberta Sustainable Resource Development

Main Floor, Great West Life Building

9920108 Street

Edmonton, Alberta, Canada T5K 2M4

Telephone: (780) 422-2079

\section{OR}

Information Service

Alberta Environment / Alberta Sustainable Resource Development \#100, 311512 Street NE

Calgary, Alberta, Canada T2E 7J2

Telephone: (403) 297-3362

\section{OR}

Visit our web site at:

http://www3.gov.ab.ca/srd/fw/riskspecies/

This publication may be cited as:

Corrigan, R. 2002. Peregrine Falcon Surveys and Monitoring in the Northeast Boreal Region of Alberta, 2001. Alberta Sustainable Resource Development, Fish and Wildlife Division, Alberta Species at Risk Report No. 57. Edmonton, AB. 12pp. 


\section{DISCLAIMER}

The views and opinions expressed are those of the author and do not necessarily represent the policies or positions of the Department or of the Alberta Government. 
Digitized by the Internet Archive in 2016

https://archive.org/details/peregrinefalcons00corr_2 


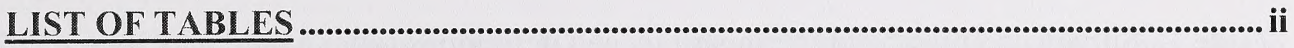

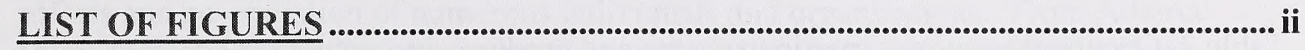

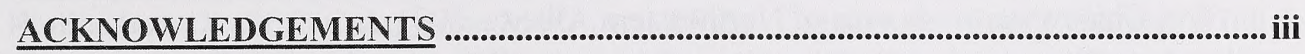

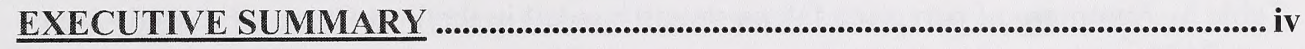

1.0 INTRODUCTION............................................................................................ 1

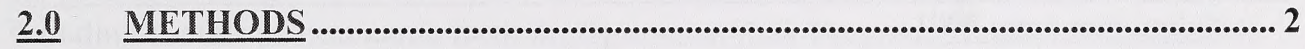

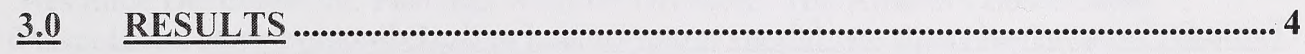

3.1. Northeastern Alberta ...................................................................................... 4

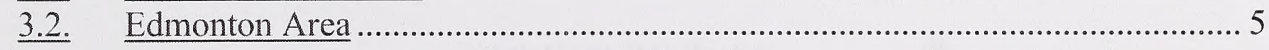

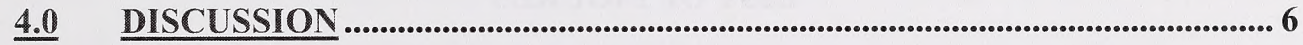

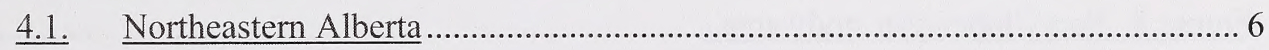

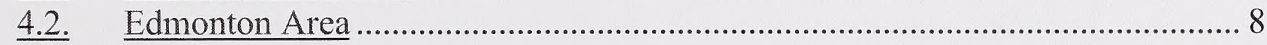

5.0 MANAGEMENT IMPLICATIONS AND FUTURE DIRECTION .............. 10

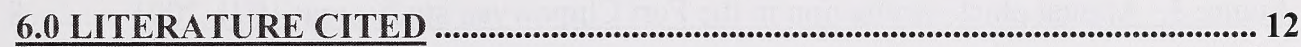




\section{LIST OF TABLES}

Table 1. Survey and monitoring terminology and definitions (after Murphy 1990). 2

Table 2 Occupied territories, nesting success and productivity of peregrine falcons in the Fort Chipewyan study area of Northeastern Alberta, 2001. ...................................... 4

Table 3. Summary of peregrine falcon young banded in the Fort Chipewyan study area,

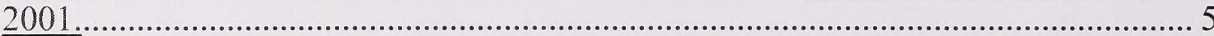

Table 4. Occupied territories, nesting success and productivity of peregrine falcons in the Edmonton area, 2001........................................................................................... 5

Table 5. Summary of peregrine falcon young banded in the Edmonton area..................... 6

\section{LIST OF FIGURES}

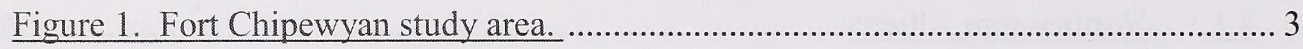

Figure 2. Territory occupancy in Fort Chipewyan Study Area: 1971-2001 ..................... 7

Figure 3. Annual chick production in the Fort Chipewyan study area; 1971-2001_.......... 8

Figure 4. Territory occupancy in the Edmonton area; 1981-2001................................... 9

Figure 5. Annual chick production in the Edmonton area; 1981-2001 .......................... 10 


\section{ACKNOWLEDGEMENTS}

Peregrine falcon monitoring in 2001 for the Northeast Region was completed through the efforts and co-operation of numerous individuals and organizations. From Alberta Sustainable Resource Development, Fish and Wildlife Division: Matt Besko, John Follinsbee, Dr. Gord Court, John Martin and Mikael Christensen, from Canadian Wildlife Service: Geoff Holroyd and Jeff Dixon, and from Wood Buffalo National Park: Mark Bradley, Barb Johnston and Libby Gunn, all assisted in surveying, monitoring and banding young. Dr. Gord Court provided technical advice and guidance throughout the completion of this project.

Funding for this project came from the Species at Risk Program of Alberta Sustainable Resource Development, Fish and Wildlife Division. The Alberta Conservation Association contributed equipment and logistical support for the completion of this project. 


\section{EXECUTIVE SUMMARY}

Historically, peregrine falcons (Falco peregrinus anatum) nested throughout Northeastern Alberta, along major river systems, Lake Athabasca and, in the Canadian shield north of Lake Athabasca. Indiscriminate use of the pesticide DDT during the 1950's and 1960's led to a decline of peregrine populations throughout north America. Peregrine falcons were extirpated in Alberta south of $58^{\circ}$ and only a small remnant population remained in the Lake Athabasca area. Due to population declines, the peregrine was listed as "endangered" in Canada in 1971 and is currently listed as "threatened" in Alberta. Following the banning of DDT in Canada, wildlife managers began intensively managing peregrines, including the development of a captive-breeding facility.

Peregrines have been monitored annually in northern Alberta since 1971, and during this period the population has increased from a low of one territorial pair in 1973, to a high of 23 , in 2000. During a provincial survey in the summer of 2000 , it was found that there were 48 pairs of territorial peregrines in Alberta. Of the 48 pairs, 29 pairs were located in the Northeast region of Alberta. Four pairs were located on urban sites in the Edmonton area, and 25 pairs were located north of $58^{\circ}$ in northeastern Alberta. Annual monitoring of all known nest sites in northern Alberta is logistically difficult due to the inaccessibility of many of the sites.

In 2001, it was agreed that Alberta Sustainable Resource Development (SRD), Wood Buffalo National Park (WBNP) and the Canadian Wildlife Service (CWS) would conduct annual occupancy and productivity monitoring in three study areas of northern Alberta. These study comprise a majority of the known nesting location in northeastern Alberta. SRD agreed to participate in annual monitoring of the Fort Chipewyan study area in conjunction with WBNP and CWS. This report presents results from surveys in the Fort Chipewyan and Edmonton area during summer 2001.

In 2001, there were ten occupied territories that produced twelve young in Fort Chipewyan. Nine young were banded at three nest sites as a component of this project. In the Edmonton area, there were six territorial pairs of peregrines that successfully fledged 16 young, of which seven were captive-raised foster young. Six pairs of peregrines represent the highest number of occupied territories in Edmonton, since they began nesting in Edmonton in 1981. Sixteen fledged young is also the greatest number of young fledged in any one breeding season. All sixteen young were banded for future identification and two young were known to have died following fledging.

It is recommended that SRD continue to participate in annual monitoring in the Fort Chipewyan study area and in the Edmonton area. This ongoing effort will allow wildlife managers to monitor population and productivity trends for recovery planning. 


\subsection{INTRODUCTION}

Due to the widespread use and environmental accumulation of pesticide residues (DDT and its derivative DDE), the peregrine falcon (Falco peregrinus anatum) population declined throughout North America during the 1950's and 1960's (Peakall et al. 1990). Since 1970, Alberta has participated in a continent-wide census that occurs every five years. As a result of the population decline, the peregrine falcon was listed as an "endangered" species in Canada in 1971 (COSEWIC 2000). By 1975, the anatum subspecies of peregrine falcons was extirpated in southern Alberta, and only a small remnant population of breeding peregrines remained in northeastern Alberta (Fyfe et al. 1976).

Following the ban of DDT in Canada in 1969, wildlife managers initiated efforts to preserve the genetic diversity of native peregrine population by establishing a captive breeding facility. The Canadian Wildlife Service (CWS) removed peregrines from wild populations to be used as breeding stock, which would eventually supply captive-raised peregrines for release into the wild. Young falcons were released into the wild in northern Alberta through fostering and into southern Alberta through a combination of fostering and hack-releases. Through these reintroduction efforts, the population of peregrines in both northern and southern Alberta has increased from three occupied territories in 1970 (Cade and Fyfe 1970) to 48 known occupied territories in 2000 (Corrigan 2000). As a result of the population increase, the species was down-listed to "threatened" in Alberta in 2000 (ESCC 2000), which followed the down-listing nationally in 1999 (COSEWIC 2000).

Throughout the decline and subsequent recovery of peregrines in Alberta, annual monitoring has been an integral component of managing this species. Due to logistical restraints and limited access to a number of northern Alberta nesting sites, not all locations could be surveyed annually for occupancy and productivity. It was decided in 2000, by Alberta Sustainable Resource Development (SRD) Fish and Wildlife Division, Wood Buffalo National Park (WBNP) and CWS, that the northern population would be divided into three study areas; Fort Chipewyan, Fort Smith and Peace Point. These three study areas would be monitored annually for occupancy and productivity, known nesting locations outside these study areas would be monitored when possible. SRD in conjunction with WBNP would be responsible for annual monitoring for the Fort Chipewyan study area. In addition to the Fort Chipewyan nest sites in northeastern Alberta, SRD continues to annually monitor the population of peregrines that breed in the Edmonton area on manmade structures.

Historically, there were twelve known peregrine nesting locations on the North Saskatchewan River between Devon and Fort Saskatchewan (Court 1993). It has been documented that recovering populations return to historical nesting locations before establishing new territories (Cade et al.1988). The exception occurs when historical nesting and foraging habitats have been altered (i.e. due to urbanization or the erection of multi-story buildings and conversion of foraging habitat to agriculture) which has occurred in the proximity of most historical nest locations in and around Edmonton. As a 
result of the creation of preferable nesting structures (tall buildings) and the recovery of southern Alberta peregrine populations, peregrines began nesting in Edmonton in 1981. Since the initial occurrence of nesting peregrines in downtown Edmonton, the number of urban territorial peregrine pairs has risen to a total of six in 2001 .

As a component of the ongoing monitoring of peregrines in the Northeast Region ${ }^{1}$ of Alberta, SRD provided funding through the Species at Risk Program in 2001 to monitor occupancy and productivity of the Fort Chipewyan study area and the population of peregrines in the Edmonton area. Specific objectives for 2001 were to:
1. Determine occupancy of the Fort Chipewyan study area and Edmonton area nest sites,
2. Determine breeding success and productivity of all nesting pairs, and
3. Band young peregrines for future identification.

${ }^{1}$ For the purpose of this report, Northeast Region refers to Alberta Government, Sustainable Resource Development regions. See www.gov.ab.ca/env/regions.html for boundaries.

\subsection{METHODS}

Terminology relating to the occupancy and productivity of peregrines was taken from Murphy (1990; Table 1).

Table 1. Survey and monitoring terminology and definitions (after Murphy 1990).

\begin{tabular}{|l|l|}
\hline \multicolumn{1}{|c|}{ Term } & \multicolumn{1}{c|}{ Definition } \\
\hline $\begin{array}{l}\text { Occupied Nest or } \\
\text { Territory }\end{array}$ & $\begin{array}{l}\text { A nest site or territory that is occupied by at least one territorial } \\
\text { adult during some part of the breeding season. }\end{array}$ \\
\hline Breeding Pair & $\bullet$ A pair that laid at least one egg during the breeding season. \\
\hline Productive Pair & $\begin{array}{l}\text { A pair that successfully raised at least one chick to an advanced } \\
\text { stage of development from which the chick was assumed to have } \\
\text { fledged. Chicks that reached an age suitable for banding are } \\
\text { considered to be of advanced age. }\end{array}$ \\
\hline $\begin{array}{l}\text { Historical Nest } \\
\text { Site }\end{array}$ & $\begin{array}{l}\text { Site that was documented to have been occupied by breeding } \\
\text { adults prior to the decline of the peregrine falcon population in } \\
\text { southern Alberta, as identified by Court (1993 a). }\end{array}$ \\
\hline Known Nest Site & $\begin{array}{l}\text { Site that has been documented to have been occupied by } \\
\text { breeding adults in any prior year (includes historic sites plus new } \\
\text { sites that have been occupied since the 1970s). }\end{array}$ \\
\hline
\end{tabular}

The Fort Chipewyan peregrine population has been annually monitored since 1971 (Court 1994). A component of this monitoring was the documentation of all known nesting territories. A total of 14 different nesting territories have been identified within 
the study area. Within a particular nesting territory, alternate nesting locations have been used, but two alternate nest sites within the same territory have never been used in the same year. All nesting territories within the Fort Chipewyan study area can be accessed by boat and all territories were visited were visited a minimum of three times to determine occupancy and breeding productivity. Site visits occurred between 11 May and 11 July 2001. Staff from WBNP and CWS conducted initial visits and second visits and the third site visits were conducted by staff from SRD, WBNP and the Alberta Conservation Association (ACA). Following the each site visit, data regarding occupancy, productivity and band information were entered into a database, which is maintained by WBNP. Nest site occupancy, productivity and banding information was also entered into the Biodiversity/Species Observation Database (BSOD), which is maintained by Alberta Fish and Wildlife Division.

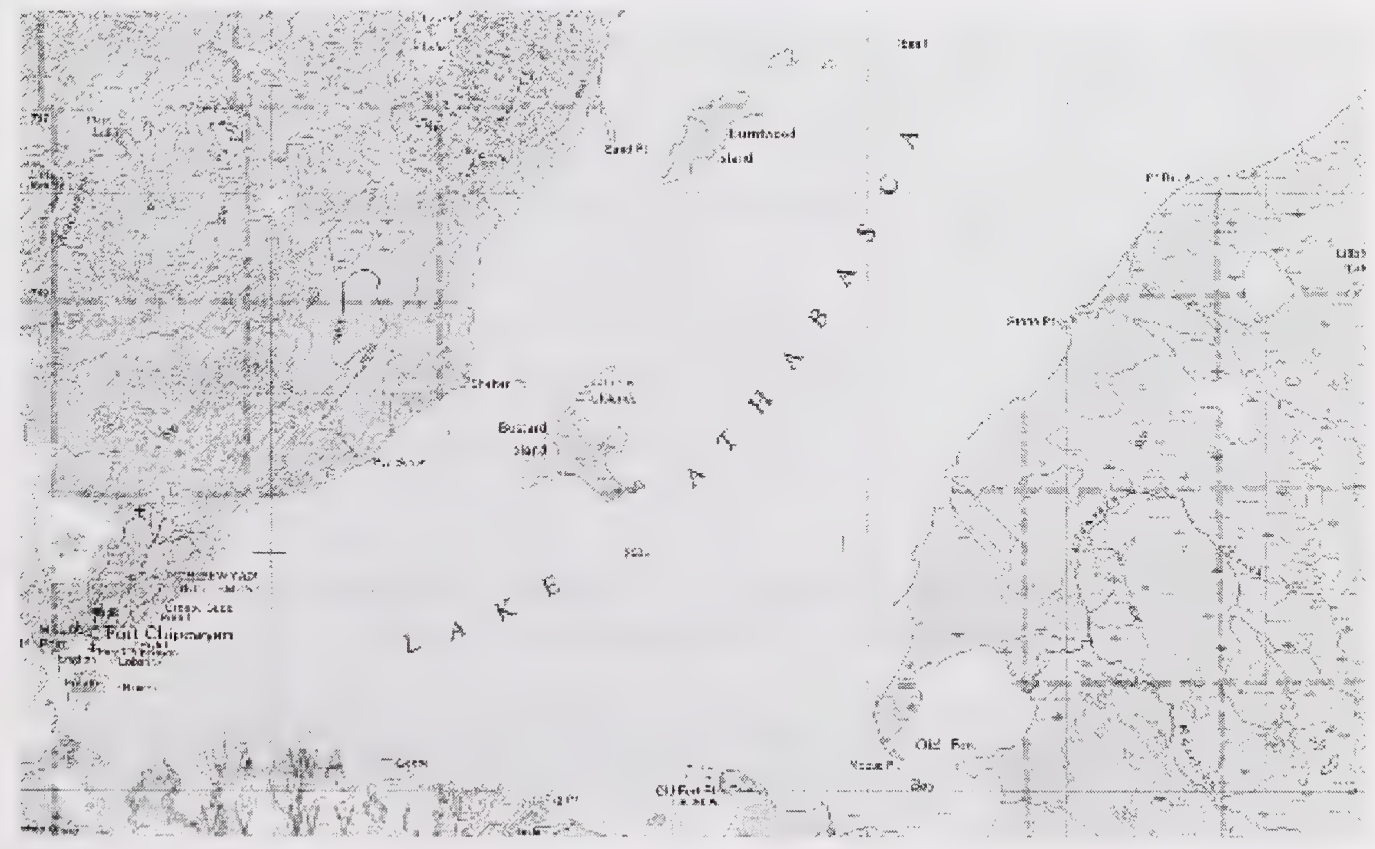

Figure 1. Fort Chipewyan study area. Spectrum Digital Imaging, Courtenay, BC, 2001.

During the third visit, young peregrines were banded with a United States Fish and Wildlife (USFWS) aluminum band on the right leg (applied with pliers) and a colored (black) alpha-numeric band on the left leg (applied with rivets). The orientation of the alpha-numeric symbols were recorded as either horizontal $(\mathrm{H})$ or vertical $(\mathrm{V})$ and whether a line (-) separated the symbols. All banding was conducted under an Alberta Environment collection licence (015 CN) and research permit (3989 GP).

Site visits in the Edmonton area occurred between 19 March and 17 September 2001. All sites were regularly monitored throughout the breeding season to determine occupancy and breeding success. Monitoring was conducted by staff from SRD, ACA and the 
public. To minimize disturbance, monitoring was conducted using a 20-60x Bausch and Lomb Elite ${ }^{\circledR}$ spotting scope. At times it was necessary to disturb adults to determine nesting chronology, when this occurred, the observer quickly left the area to a distance that no longer agitated the adults. Young peregrines were banded using the methods described above and all information was also entered into BSOD. Any nests that contained less than four natural young were considered for fostering of captive-raised young if ages were compatible. Fostering captive-raised young augments natural productivity that increases the overall number of young entering a population.

\subsection{RESULTS}

\subsection{Northeastern Alberta}

During the 2001-breeding season there were eleven occupied territories in the Fort Chipewyan study area. One territory (Potato Island) was occupied by a single adult male, the remaining sites were all occupied by territorial pairs (Table 2). Of the ten sites occupied by territorial pairs, eight sites were successful at breeding and four sites successfully raised young (Table 2). The estimated total number of young produced in the Fort Chipewyan study was twelve. During the third visit, both adults aggressively defended the nesting site, indicating the presence of young. By assigning the average brood size $(n=3)$ of the remaining productive sites, a total of twelve young were produced. A total of nine young were banded at three sites during 2001 (Table 3). Young were not counted or banded at Shelter Point due to the mechanical breakdown of the boat and the inability to access the site.

Table 2 Occupied territories, nesting success and productivity of peregrine falcons in the Fort Chipewyan study area of Northeastern Alberta, 2001.

\begin{tabular}{||l|c|c|c||}
\hline Site Name & Breeding Pair & Productive Pair & \# of Fledged Young \\
\hline Pine Island & Yes & Yes & 3 \\
\hline Potato Island & No & No & 0 \\
\hline Halfway Island & No & No & 0 \\
\hline Point Basse & Yes & No & 0 \\
\hline Shelter Point & Yes & Yes & $\left(3^{*^{2}}\right)$ \\
\hline Close Call & Yes & No & 0 \\
\hline Dog Head & Yes & No & 0 \\
\hline Unnamed Island & Yes & No & 0 \\
\hline Pushup Lake & No & No & 0 \\
\hline Grouse Cape & Yes & Yes & 2 \\
\hline Wood Island & Yes & Yes & 4 \\
\hline \hline
\end{tabular}

Territory occupied by a single adult male.

${ }^{*}$ Young were not counted, the average clutch size was applied to this nest site. 
Table 3. Summary of peregrine falcon young banded in the Fort Chipewyan study area, 2001.

\begin{tabular}{||l|c|c|l||}
\hline Site Name & Alpha-numeric & USFWS & Comments \\
\hline Grouse Cape & B C/R (VH) & $816-34585$ & Male \\
& B L/R (VH) & $1807-78687$ & Female \\
\hline Pine Island & B K/S (VH) & $1807-78735$ & Female \\
& B W/S (VH) & $1807-78720$ & Female \\
& B C/S (VH) & $816-34529$ & Male \\
\hline Wood Island & B K/R (VH) & $816-34524$ & Male \\
& B V/S (VH) & $816-34531$ & Male \\
& B P/S (VH) & $1807-78698$ & Female \\
& B U/S (VH) & $1807-78719$ & Female \\
\hline
\end{tabular}

\subsection{Edmonton Area}

During the 2001-breeding season, six occupied territories were identified in the Edmonton area (Table 4). Territorial pairs occupied all sites throughout the breeding season, except at the Clinical Sciences site, where there were two adult females and one adult male occupied this site. Four of the six sites were successful in breeding and laid at least one egg, with three sites producing young to fledging age. A total of 16 young were raised to an advanced age and were assumed to have fledged. Of the 16 young, seven young were captive-raised and fostered into four sites (Table 4). All of the 16 young were banded with USFWS and alpha-numeric bands and two of these young were found dead following fledging (Table 5).

Table 4. Occupied territories, nesting success and productivity of peregrine falcons in the Edmonton area, 2001.

\begin{tabular}{||l|c|c|c||}
\hline Site Name & Breeding Pair & Productive Pair & \# of Fledged Young \\
\hline Inland Cement & Yes & Yes & $4 *(1)$ \\
\hline Downtown-Telus & Yes & Yes & $4 *(1)$ \\
\hline Clinical Sciences & Yes & No & $4 *(4)$ \\
\hline Weber Centre & No & No & 0 \\
\hline Esso Plant & No & No & 0 \\
\hline Agrium & Yes & Yes & $4 *(1)$ \\
\hline
\end{tabular}

* ( ) indicates the number of captive-raised foster young 
Table 5. Summary of peregrine falcon young banded in the Edmonton area

\begin{tabular}{||l|l|l|l||}
\hline Site Name & Young (C) & \multicolumn{1}{l||}{ Young (Al) } & Comments \\
\hline Inland Cement & B KX (VH) & $987-29817$ & Female-found dead \\
& B A/X (VH) & $987-29818$ & Female \\
& B 2/H (HV) & $816-34145$ & Male \\
& R HN (VV) & $987-29819$ & Female-foster young \\
\hline Downtown & B U/9 (HV) & $1807-78657$ & Female \\
& B O/Z (VV) & $1807-78658$ & Female \\
& B O/Y (VV) & $816-34173$ & Male \\
& R 9A6 (VV) & $1807-78659$ & Female-foster young \\
\hline Clinical & R 29 (VV) & $987-29826$ & Male-foster young \\
Sciences & R 28 (VV) & $816-34182$ & Male- foster young \\
& R K/E (VV) & $1807-78680$ & Female- foster young \\
& R KC (VV) & $1807-78664$ & Female- foster young \\
\hline Fort Sask. & B S/X (VH) & $987-29816$ & Female \\
(Agrium) & B R/X (VH) & $987-29810$ & Female \\
& B PN (VH) & $816-16794$ & Male \\
& R 5S (HV) & $816-34122$ & Female- foster, found dead \\
\hline
\end{tabular}

\subsection{DISCUSSION}

\subsection{Northeastern Alberta}

The number of occupied territories in the Fort Chipewyan study area has increased significantly since annual monitoring began in 1971. In 1973, there was only one occupied territory, and has increased to a high in 2000 , when twelve territories were occupied (Figure 1). However, the rate of increase has slowed since 1995, with occupancy fluctuating between nine and twelve territories annually. Before the first intensive survey that occurred for peregrines in Northeastern Alberta in 1970 (Cade and Fyfe 1970), populations had already declined, therefore, a true historical population estimate is unknown. Determining when the population stabilizes and reaches carrying capacity can only be determined through a standard monitoring program. Recovery planning is dependent upon the availability of long-term population trend data. 


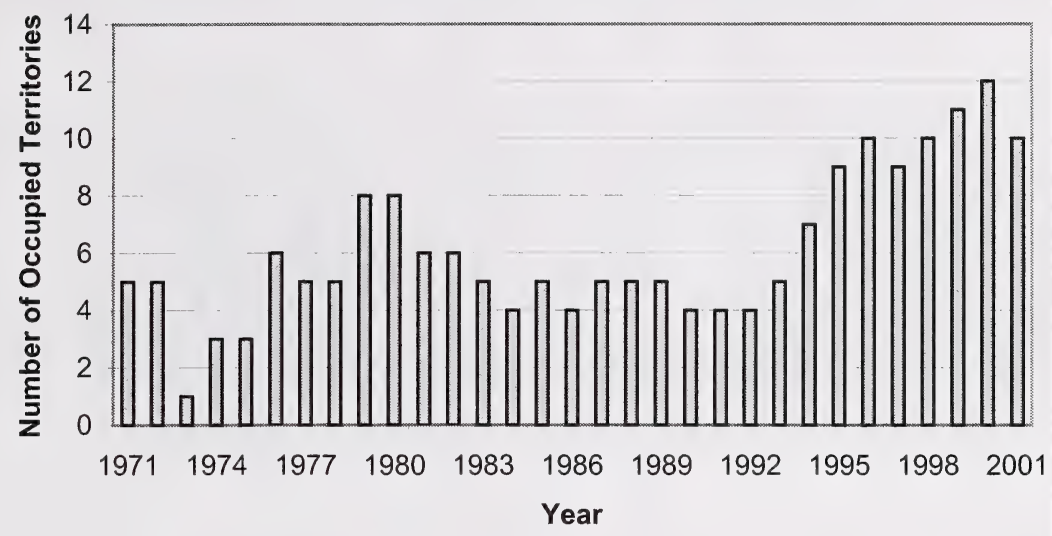

Figure 2. Territory occupancy in Fort Chipewyan Study Area; 1971-2001 (Alberta Fisheries and Wildlife unpublished data, Wood Buffalo National Park and Northeastern Alberta Peregrine Falcon Monitoring 2001, unpublished data).

Annual production of young has been highly variable in the Fort Chipewyan study area. Production of young has fluctuated from zero (1973, 1975, 1976, 1981, 1982 and 1986) to a high of 22, in 1997 (Figure 2). Since 1995, production has remained at over twelve young produced annually, except in 2000, when only four young produced. In 2001, an estimated twelve young were produced, which is below the average for 1995-2001 of fourteen. Although the occupancy rate has appeared to stabilize since 1995, productivity remains variable. Ongoing monitoring of productivity will allow managers to determine if a downward trend in reproductive success is developing in the Fort Chipewyan study area. Being able to compare occupancy and productivity of the Fort Chipewyan study area against Fort Smith and Peace Point will enable managers to determine if trends that are developing are regional in scope or confined to a much smaller area. 


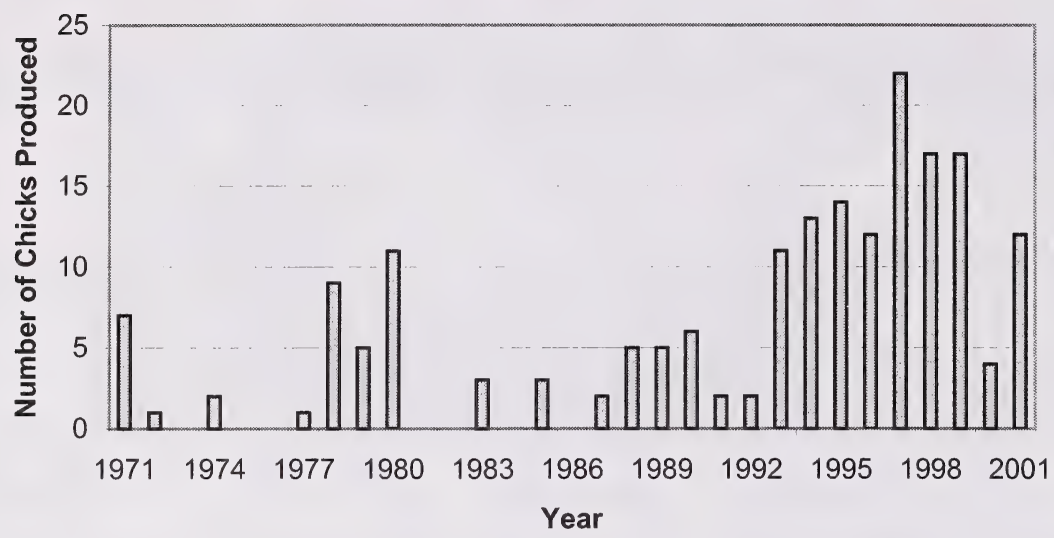

Figure 3. Annual chick production in the Fort Chipewyan study area; 1971-2001. (Alberta Fisheries and Wildlife unpublished data, Wood Buffalo National Park and Northeastern Alberta Peregrine Falcon Monitoring 2001, unpublished data).

\subsection{Edmonton Area}

Within the Edmonton area there were twelve known peregrine falcon historical nesting locations on the North Saskatchewan River and its tributaries between Devon and Fort Saskatchewan (Court 1993). Recovering populations of peregrines have shown a propensity to return to historical sites during subsequent recovery periods (Cade and Fyfe 1970, Court 1993). None of the historical nesting locations within the Edmonton area have been re-occupied during the recovery of peregrines in Alberta. The absence of territorial pairs can be attributed to a variety of factors. Many of the historical nesting sites are now unsuitable for nesting peregrines. The cliffs have slumped, vegetation has encroached and urban development has occurred on top of numerous cliffs. High-quality foraging habitat has been lost in rural areas due the conversion of habitat to agriculture. In addition to historical nesting habitat becoming unsuitable, new high quality nest sites have been developed (buildings) in the Edmonton area. Tall urban buildings provide high "cliff-like" structures, relatively free from natural predators with abundant prey, which may make urban buildings, preferred nesting sites.

Following the extirpation of peregrines in southern Alberta by 1975 (Fyfe et al. 1976), the first peregrines to successfully breed in southern Alberta occurred in 1981, in downtown Edmonton. Peregrines continued to nest in Southern Alberta urban centres exclusively until 1991, when they were first documented in central Alberta (Stepnisky 1996). The 2000 Provincial Peregrine Falcon Survey found that 14 of 23 known nesting locations in southern Alberta were in urban centres or on man-made structures (Corrigan 2000). This indicates that peregrines continue to have a preference for urban and manmade environments over historical rural nesting locations. A new territorial pair of peregrines was observed in 2001 at the Imperial Oil refinery, which indicates that 
peregrines will continue to choose urban environments over historical nesting sites. It is unlikely that peregrines will return to historical nesting locations in the Edmonton area.

The number of occupied territories in Edmonton during the 2001-breeding season was six, which is the highest number since peregrines began nesting in Edmonton in 1981 (Figure 3). Four of the six pairs were successful breeders, and three sites fledged a total of nine natural born young. In addition, seven captive-raised young were also fledged through fostering. Young were fostered at the four sites that were successful breeders and laid eggs. The total number of fledged young for the 2001-breeding season in Edmonton was 16, and represents the greatest number of young produced in the Edmonton area (Figure 4).

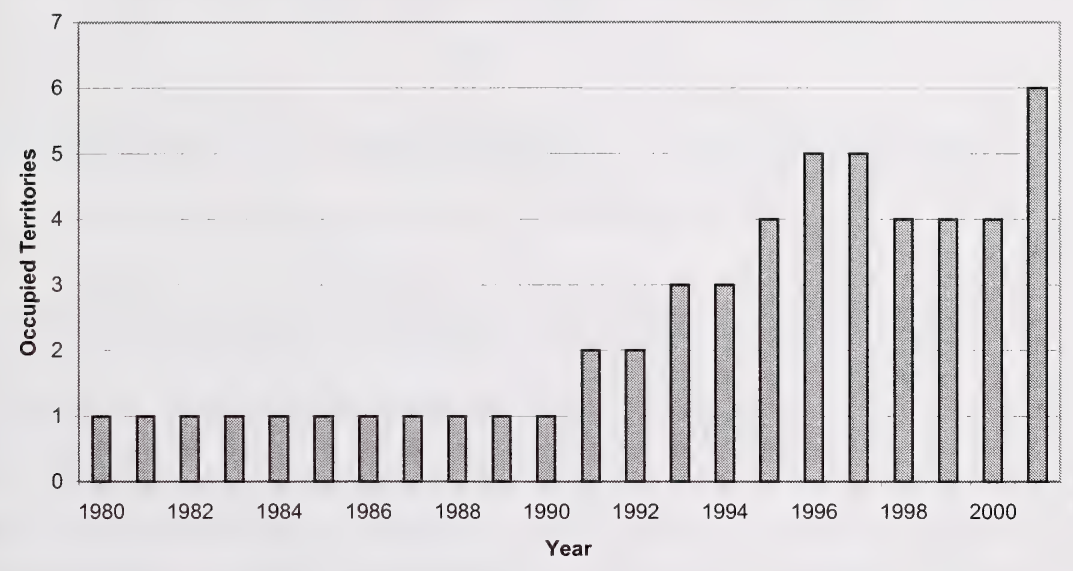

Figure 4. Territory occupancy in the Edmonton area; 1981-2001 (Alberta Fisheries and Wildlife unpublished data).

At the Clinical Sciences site, two adult females and one adult male occupied and actively defended the site throughout the breeding season. Seven eggs were laid and incubated by both females during the breeding season, but all the eggs were infertile and collected for pesticide analysis. Four captive-raised young were successfully fledged from this site, and all three adults were observed participating in feeding and rearing of the young. In the Edmonton area two young were found dead following fledging, one natural born female young at the Inland Cement site and one female foster young at the Fort Saskatchewan (Agrium) site. 


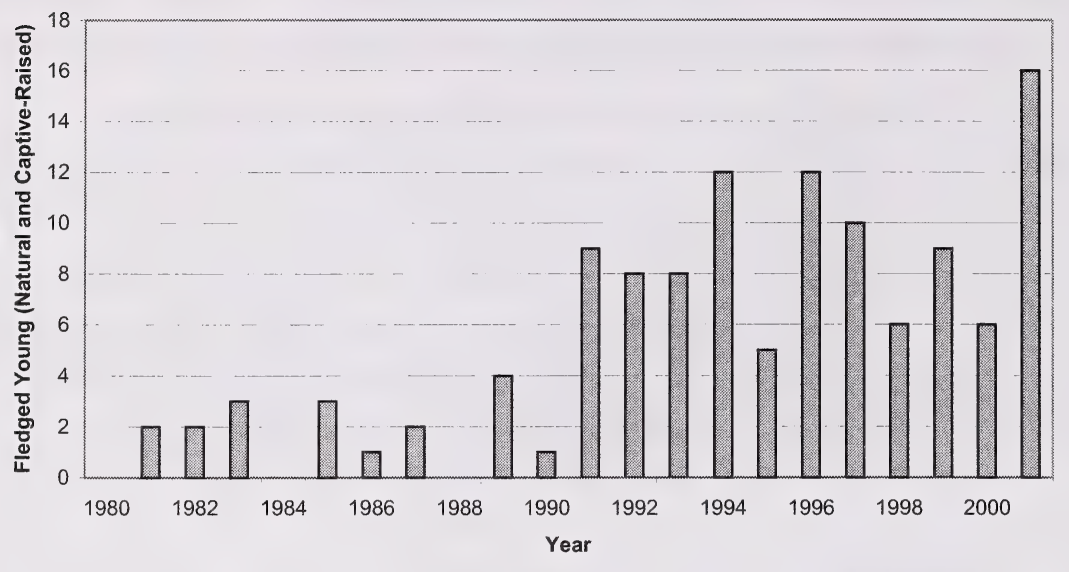

Figure 5. Annual chick production in the Edmonton area; 1981-2001 (Alberta Fisheries and Wildlife unpublished data).

\subsection{MANAGEMENT IMPLICATIONS AND FUTURE DIRECTION}

Currently, the peregrine falcon is listed as a "threatened" species, both provincially and nationally (ESCC 2000, COSEWIC 2000). It is unknown whether peregrine population provincially is approaching historical population levels because there are no accurate predecline population estimates. In order to determine that peregrines are approaching carrying capacity, ongoing annual monitoring is needed. Productivity in peregrine populations has a high degree of variability and relying on five-year provincial surveys will not provide accurate information of occupancy and productivity trends.

Standardized annual monitoring of specific populations will provide biologists and managers the necessary information to determine when peregrines are reaching carrying capacity. This information can also provide an early warning should populations and/or productivity decline. A co-operative effort between SRD, WBNP and CWS should continue in Northeastern Alberta in the three established study areas. A formal Memorandum of Understanding (MOU) outlining agency responsibility needs to be developed that would remain in effect through the 2005 national peregrine falcon survey.

Annual monitoring in the Edmonton area should also continue under the direction of SRD. Monitoring in Edmonton can be done relatively easily with no additional allocation of resources. In sites where peregrines show a territorial affinity, suitable nesting structures should be erected (i.e. Weber Centre). Providing a nesting structure greatly increases the likelihood nesting and fledging success. The peregrine falcons in Edmonton have provided an exceptional opportunity for public education and awareness, and continue to do so. In addition to annual monitoring, an effort should be made to facilitate the compilation, storage and management of peregrine falcon population and biological data. Banding of young should continue if an effort is to be made in the future to identify territorial peregrines. This will enable mangers to determine the 
demographics of the recovering population. Satellite transmitters may be used to monitor juvenile dispersal and assist in determining the linkages between nesting and foraging habitat. 


\subsection{LITERATURE CITED}

Cade, T.J. and R. Fyfe. 1970. The North American peregrine survey, 1970. Can. FieldNaturalist. 84:231-245.

Cade, T.J., J.H. Enderson, C.G. Thelander and C.M. White (Editors). 1988. Peregrine falcon populations: their management and recovery. The Peregrine Fund Inc. Boise, Idaho.

Corrigan, R. 2000. Survey of the peregrine falcon (Falco peregrinus anatum) in Alberta. Alberta Sustainable Resource Development, Fish and Wildlife Service, Alberta Species at Risk Report No. 2. Edmonton, AB. 17pp.

COSEWIC. 2000. Canadian species at risk, November 2000. Committee on the status of endangered wildlife in Canada. $24 \mathrm{pp}$.

Court, G.S. 1993. A review of historical nesting records for the Peregrine Falcon ( Falco peregrinus anatum) in Alberta south of $56^{\circ} \mathrm{N}$ : priorities for a recovering population. Unpubl. rept., Alberta Fish and Wildlife Division, Edmonton, AB.

Court, G.S. 1994. Population dynamics of American Peregrine Falcon (Falco peregrinus anatum) breeding in northeastern Alberta, Canada- 1971 to 1993: an evaluation of the need for continued management. Alberta Environmental Protection, Fish and Wildlife Services, Occasional Report Series No. 14. Edmonton, AB. 25 pp.

Endangered Species Conservation Committee. 2000. First report of the Alberta Endangered Species Conservation Committee. Alberta Environment, Fisheries and Wildlife Management Division. 24 pp.

Fyfe, R. W., S. A. Temple, and T. J. Cade. 1976. The North American peregrine falcon survey. Can. Field-Naturalist 90: 228-273.

Murphy, J. E. 1990. The 1985-86 Canadian Peregrine Falcon, Falco peregrinus, survey. Canadian Field-Naturalist 104:182-192.

Peakall, D.B., D.G. Noble, J.E. Elliot, J.D. Somers and G. Erikson. 1990. Environmental contaminants in Canadian Peregrine Falcons, Falco peregrinus: a toxicological assessment. Canadian Field-Naturalist 104:244-254.

Stepinsky, D.P. 1998. Demographic Features of the Recovering Peregrine Falcon Population (Falco peregrinus anatum) in Southern Alberta: 1980-1997. Occasional Report Series Number 15. Alberta Environmental Protection, Natural Resources Service, Edmonton, AB. 


\section{List of Titles in This Series}

(as of August 2002)

No. 1 Alberta species at risk program and projects 2000-2001, by Alberta Sustainable Resource Development, Fish and Wildlife Division. (2001)

No. 2 Survey of the peregrine falcon (Falco peregrinus anatum) in Alberta, by R. Corrigan. (2001)

No. 3 Distribution and relative abundance of the shortjaw cisco (Coregonus zenithicus) in Alberta, by M. Steinhilber and L. Rhude. (2001)

No. 4 Survey of the bats of central and northwestern Alberta, by M.J. Vonhof and D. Hobson. (2001)

No. 52000 survey of the Trumpeter Swan (Cygnus buccinator) in Alberta, by M.L. James and A. James. (2001)

No. 6 2000/2001 Brassy Minnow inventory at Musreau Lake and outlet, by T. Ripley. (2001)

No. 7 Colonial nesting waterbird survey in the Northwest Boreal Region - 2000, by M. Hanneman and M. Heckbert. (2001)

No. 8 Burrowing owl trend block survey and monitoring - Brooks and Hanna areas, by D. Scobie and R. Russell. (2000)

No. 9 Survey of the Lake Sturgeon (Acipenser fulvescens) fishery on the South Saskatchewan River, Alberta (June-September, 2000), by L.A. Winkel. (2000)

No. 10 An evaluation of grizzly bear-human conflict in the Northwest Boreal Region of Alberta (19912000) and potential mitigation, by T. Augustyn. (2001)

No. 11 Harlequin duck monitoring in the Northern East Slopes of Alberta: 1998-2000 preliminary results, by J. Kneteman and A. Hubbs. (2000)

No. 12 Distribution of selected small mammals in Alberta, by L. Engley and M. Norton. (2001)

No. 13 Northern leopard frog reintroduction. Raven River - Year 2 (2000), by K. Kendell. (2001)

No. 14 Cumulative effects of watershed disturbances on fish communities in the Kakwa and Simonette watersheds. The Northern Watershed Project. Study 3 Progress report, by T. Thera and A. Wildeman. (2001)

No. 15 Harlequin duck research in Kananaskis Country in 2000, by C.M. Smith. (2001)

No. 16 Proposed monitoring plan for harlequin ducks in the Bow Region of Alberta, by C.M. Smith. (2001)

No. 17 Distribution and relative abundance of small mammals of the western plains of Alberta as determined from great horned owl pellets, by D. Schowalter. (2001)

No. 18 Western blue flag (Iris missouriensis) in Alberta: a census of naturally occurring populations for 2000 , by R. Ernst. (2000)

No. 19 Assessing chick survival of sage grouse in Canada, by C.L. Aldridge. (2000)

No. 20 Harlequin duck surveys of the Oldman River Basin in 2000, by D. Paton. (2000) 
No. 21 Proposed protocols for inventories of rare plants of the Grassland Natural Region, by C. Wallis. (2001)

No. 22 Utilization of airphoto interpretation to locate prairie rattlesnake (Crotalus viridis viridis) hibernacula in the South Saskatchewan River valley, by J. Nicholson and S. Rose. (2001)

No. 23 2000/2001 Progress report on caribou research in west central Alberta, by T. Szkorupa. (2001)

No. 24 Census of swift fox (Vulpes velox) in Canada and Northern Montana: 2000-2001, by A. Moehrenschlager and C. Moehrenschlager. (2001)

No. 25 Population estimate and habitat associations of the long-billed curlew in Alberta, by E.J. Saunders. (2001)

No. 26 Aerial reconnaissance for piping plover habitat in east-central Alberta, May 2001, by D.R.C. Prescott. (2001)

No. 27 The 2001 international piping plover census in Alberta, by D.R.C. Prescott. (2001)

No. 28 Prairie rattlesnake (Crotalus viridis viridis) monitoring in Alberta - preliminary investigations (2000), by S.L. Rose. (2001)

No. 29 A survey of short-horned lizard (Phrynosoma hernandesi hernandesi) populations in Alberta, by J. James. (2001)

No. 30 Red-sided garter snake (Thamnophis sirtalis parietalis) education and relocation project - final report, by L. Takats. (2002)

No. 31 Alberta furbearer harvest data analysis, by K.G. Poole and G. Mowat. (2001)

No. 32 Measuring wolverine distribution and abundance in Alberta, by G. Mowat. (2001)

No. 33 Woodland caribou (Rangifer tarandus caribou) habitat classification in northeastern Alberta using remote sensing, by G.A. Sanchez-Azofeifa and R. Bechtel. (2001)

No. 34 Peregrine falcon surveys and monitoring in the Parkland Region of Alberta, 2001, by R. Corrigan. (2002)

No. 35 Protocol for monitoring long-toed salamander (Ambystoma macrodactylum) populations in Alberta, by T. Pretzlaw, M. Huynh, L. Takats and L. Wilkinson. (2002)

No. 36 Long-toed salamander (Ambystoma macrodactylum) monitoring study in Alberta: summary report 1998-2001, by M. Huynh, L. Takats and L. Wilkinson. (2002)

No. 37 Mountain plover habitat and population surveys in Alberta, 2001, by C. Wershler and C. Wallis. (2002)

No. 38 A census and recommendations for management for western blue flag (Iris missouriensis) in Alberta, by R. Ernst. (2002)

No. 39 Columbian mountain amphibian surveys, 2001, by D. Paton. (2002)

No. 40 Management and recovery strategies for the Lethbridge population of the prairie rattlesnake, by R. Ernst. (2002) 
No. 41 Western (Aechmophorus occidentalis) and eared (Podiceps nigricollis) grebes of central Alberta: inventory, survey techniques and management concerns, by S. Hanus, H. Wollis and L. Wilkinson. (2002)

No. 42 Northern leopard frog reintroduction - year 3 (2001), by K. Kendell. (2002)

No. 43 Survey protocol for the northern leopard frog, by K. Kendell. (2002)

No. 44 Alberta inventory for the northern leopard frog (2000-2001), by K. Kendell. (2002)

No. 45 Fish species at risk in the Milk and St. Mary drainages, by RL\&L Environmental Services Ltd. (2002)

No. 46 Survey of the loggerhead shrike in the southern aspen parkland region, 2000-2001, by H. Kiliaan and D.R.C. Prescott. (2002)

No. 47 Survey of native grassland butterflies in the Peace parkland region of northwestern Alberta - 2001, by M. Hervieux. (2002)

No. 48 Caribou range recovery in Alberta: 2001/02 pilot year, by T. Szkorupa. (2002)

No. 49 Peace parkland native grassland stewardship program 2001/02, by A. Baker. (2002)

No. 50 Carnivores and corridors in the Crowsnest Pass, by C. Chetkiewicz. (2002)

No. 512001 Burrowing owl trend block survey and monitoring, Brooks and Hanna areas, by D. Scobie. (2002)

No. 52 An evaluation of the ferruginous hawk population in Alberta based on recent trend data, by D.P. Stepnisky, G.L. Erickson, J. Iwaasa and B. Taylor. (2002)

No. 53 Alberta amphibian call surveys. A pilot year. Final report, by L. Takats and C. Priestley. (2002)

No. 54 Utilization of a roadside survey technique to survey burrowing owl (Athene cunicularia hypugaea) in southeastern Alberta, by J. Nicholson and C. Skiftun. (2002)

No. 55 Alberta species at risk program and projects 2001-2002, by Alberta Sustainable Resource Development, Fish and Wildlife Division (2002)

No. 56 Developing a habitat-based population viability model for greater sage-grouse in southeastern Alberta, by C.L. Aldridge (2001) 


Library and Archives Canada
Bibliotheque et Archives Canada

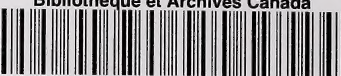

33286532180474 